\title{
EPR Oximetry Sensor-Developing a TAM Derivative for In Vivo Studies
}

\author{
Agnieszka Boś-Liedke (ii) ${ }^{1,2} \cdot$ Magdalena Walawender $^{1} \cdot$ Anna Woźniak $^{1} \cdot$ \\ Dorota Flak $^{1}$ - Jacek Gapiński ${ }^{1,2}$ - Stefan Jurga ${ }^{1,2}$ • Małgorzata Kucińska ${ }^{3}$. \\ Adam Plewiński ${ }^{3} \cdot$ Marek Murias $^{3}$ - Marwa Elewa ${ }^{4} \cdot$ Lisa Lampp ${ }^{5}$ - Peter Imming ${ }^{5}$. \\ Krzysztof Tadyszak ${ }^{1,6}$
}

Received: 1 February 2017 / Accepted: 14 August 2017 / Published online: 4 September 2017

(C) The Author(s) 2017. This article is an open access publication

\begin{abstract}
Oxygenation is one of the most important physiological parameters of biological systems. Low oxygen concentration (hypoxia) is associated with various pathophysiological processes in different organs. Hypoxia is of special importance in tumor therapy, causing poor response to treatment. Triaryl methyl (TAM) derivative radicals are commonly used in electron paramagnetic resonance (EPR) as sensors for quantitative spatial tissue oxygen mapping. They are also known as magnetic resonance imaging (MRI) contrast agents and fluorescence imaging compounds. We report the properties of the TAM radical tris(2,3,5,6-tetrachloro-4-carboxy-phenyl)methyl, (PTMTC), a potential multimodal (EPR/fluorescence) marker. PTMTC was spectrally analyzed using EPR and characterized by estimation of its sensitivity to the oxygen in liquid environment suitable for intravenous injection ( $1 \mathrm{mM} \mathrm{PBS}, \mathrm{pH}=7.4)$.
\end{abstract}

Agnieszka Boś-Liedke

agnbos@amu.edu.pl

$\triangle$ Krzysztof Tadyszak

krztad@amu.edu.pl

1 NanoBioMedical Centre, Adam Mickiewicz University, ul. Umultowska 85, 61614 Poznań, Poland

2 Faculty of Physics, Adam Mickiewicz University, ul. Umultowska 14, 61614 Poznań, Poland

3 Department of Toxicology, Poznan University of Medical Sciences, ul. Dojazd 30, 60631 Poznan, Poland

4 Faculty of Pharmacy, Suez Canal University, P.O. 41522, Ismailia, Egypt

5 Institute of Pharmacy, Martin Luther University Halle-Wittenberg, Wolfgang-Langenbeck-Str. 4, 06120 Halle (Saale), Germany

6 Institute of Molecular Physics, Polish Academy of Sciences, ul. M. Smoluchowskiego 17, 60179 Poznań, Poland
Further, fluorescent emission of the radical was measured using the same solvent and its quantum yield was estimated. An in vitro cytotoxicity examination was conducted in two cancer cell lines, HT-29 (colorectal adenocarcinoma) and $\mathrm{FaDu}$ (squamous cell carcinoma) and followed by uptake studies. The stability of the radical in different solutions (PBS pH $=7.4$, cell media used for HT-29 and FaDu cells culturing and cytotoxicity procedure, full rat blood and blood plasma) was determined. Finally, a primary toxicity test of PTMTC was carried out in mice. Results of spectral studies confirmed the multimodal properties of PTMTC. PTMTC was demonstrated to be not absorbed by cancer cells and did not interfere with luciferin-luciferase based assays. Also in vitro and in vivo tests showed that it was non-toxic and can be freely administrated till doses of 250 $\mathrm{mg} / \mathrm{kg}$ BW via both i.v. and i.p. injections. This work illustrated that PTMTC is a perfect candidate for multimodal (EPR/fluorescence) contrast agent in preclinical studies.

Keywords EPR oximetry $\cdot$ TAM derivative $\cdot$ Oxygenation sensor $\cdot$ Cytotoxicity

\section{Introduction}

The concentration of oxygen in tissues is one of the most crucial physiological parameters [1]. In most healthy tissues, the oxygen partial pressure $\left(\mathrm{pO}_{2}\right)$ ranges between 10 and $80 \mathrm{mmHg}$. Low oxygen concentration (hypoxia) is associated with various pathophysiological processes in different organs, e.g., stroke or cancer. In solid tumors, fast angiogenesis of the cancer cells stimulates the creation of 
chaotic and poorly organized vasculature that in turn results in deprivation of both oxygen $\left(\mathrm{pO}_{2}<5 \mathrm{mmHg}\right)$ and nutrients supply to the tissue that further stimulates even faster angiogenesis of the pathological cells [2]. In those tissues hypoxia is of special importance causing a poor response of the tumor to radio-, chemo- or even surgical treatment $[3,4]$. Resistivity of the cancer tissues due to low oxygen content is explained by limited interaction of the oxygen with radicals formed by radiation. Those products cause DNA damages that cannot be easily repaired [5]. Furthermore, hypoxia increases also a predisposition to metastasis and is associated with poor prognosis and survival rate of the patients [6].

The first hypoxia studies appeared in the nineteenth century and were closely related to the recently developed discipline of radiation oncology - a combination of medicine, physics, chemistry, engineering and biology. At the same time it became clear that improvement of radiotherapeutical medical care is closely related to its quantitative planning, careful documentation, determination of toxicity, and benefits for patients, as well as development of new imaging techniques and technology in this field. This fact became a motivation for analyzing physiological parameters, like perfusion or oxygenation of the cancer tissue that change, upon treatment and have an influence on its efficiency. The quantitative measurement of those parameters during applied radiochemotherapy would significantly help in prediction of therapy success and evaluation of its effectiveness [7]. Therefore, the quantification of such parameters, monitoring of their changes and imaging of distribution in time became mandatory in radiation oncology.

Until today, methods for hypoxia imaging in human cancers have been accomplished with highly sensitive but low resolution methods presented by nuclear medicine, i.e., ${ }^{18} \mathrm{~F}$-fluoromisonidazole positron emission tomography (PET) (F-18-FMISO-PET); and with qualitative radiological methods, e.g., blood oxygen level-dependent magnetic resonance imaging (BOLD-MRI), dynamic contrast-enhance MRI (DCE-MRI), Overhauser MRI (OMRI), contrast enhanced computer tomography, electron paramagnetic resonance imaging, and ${ }^{19} \mathrm{~F}$ oximetry [8-13]. Only some of them allow not only for qualitative, but also for quantitative evaluation of tissue oxygenation. One of the best examples and widely used in clinics is F-18 FMISO PET. This technique uses an intravenously injected dose of radioactive isotope (F-18) as a signal source that is targeted by metabolism of nitroimidazole in cells [14]. Another method used for quantitative imaging is electron paramagnetic resonance (EPR) oxymetry. It delivers not only spectroscopic information about the partial pressure of the oxygen deposited in the tissues, but also allows the creation of $3 \mathrm{D}$ and $4 \mathrm{D}$ tomographic images. The amount of paramagnetic molecular oxygen present in biological systems is indicated by the linewidth broadening of the intravenously (i.v.) or intraperitoneal (i.p.) injected soluble paramagnetic spin probe. The broadening results from Heisenberg exchange between molecular $\mathrm{O}_{2}$ dissolved in the blood and the radical [15]. Although the material is also injected into the blood stream, it is not radioactive, so the delivery to the patient does not requires special procedures, protection and trainings of the staff, longer hospitalization of the patients that are exposed to the radiation. In contrast to radionuclide probes, the spin probes can be stored for a long time and need not be produced just before use. Among soluble spin probes, two types are of special interest for diagnostic purposes, namely nitroxides and triarylmethyl (TAM) radicals. Although nitroxides present a number of different properties that can be manipulated, the TAM radicals are particularly convenient for in vivo imaging application because of their very narrow, single EPR lines. Line widths are less than 100 mGauss and linearly dependent on the oxygen concentration with high sensitivity [16].

TAM radicals also found an application in MRI $[11,17]$ by use of the Overhauser effect. Furthermore, some of them are photosensitive and capable to fluorescence. This property has never been deeply studied in preclinical and clinical aspects. According to our knowledge, the only research in this line was published in 1944 by Lewis, Lipkin, and Magel under the title "The Light Absorption and Fluorescence of Triarylmethyl Free Radicals" [18]. All of the mentioned properties make TAM radicals suitable candidates for multimodal imaging contrast agents.

Due to the importance of the preclinical and clinical significance of tissue oxygenation estimation and imaging, an increasing number of EPR TAM radicals are being evaluated. This study reports on EPR oxygen sensor based on TAM derivative, which is a potential candidate for an efficient multimodal imaging. As a potential in vivo hypoxia marker for EPR imaging, the PTMTC TAM radical was firstly characterized towards its sensitivity to the oxygen in liquid media suitable for intravenous injection $(1 \mathrm{mM}$ PBS, $\mathrm{pH}=7.4$ ). Then the fluorescence of the radical in PBS was measured and its quantum yield was determined. Cytotoxicity was examined using two cell lines, HT-29 (colorectal adenocarcinoma, less hypoxic) and $\mathrm{FaDu}$ (squamous cell carcinoma, more hypoxic). Also the stability of the radical in different solutions ( $\mathrm{PBS} \mathrm{pH}=7.4$, cell media used for HT-29 and FaDu cell culturing and cytotoxicity procedure, full rat blood, and blood plasma) was determined. The cytotoxicity test was followed by additional studies focused on PTMTC uptake by cancer cells and its interference with luciferin-luciferase-based assays. Finally, PTMTC was administrated to the Balb/c mice at the dose of $250 \mathrm{mg} / \mathrm{kg}$ BW via i.v. and i.p. injections to estimate its in vivo toxicity. 


\section{Materials and Methods}

\section{Synthesis}

\section{Tris(4-carboxy-2,3,5,6-tetrachloro-phenyl)methyl radical} (PTMTC)

Note: When the radicals are in solution, light should be excluded.

Tris(4-ethoxy-carbonyl-2,3,5,6-tetrachlorophenyl)methyl radical $[19,20]$ (500 $\mathrm{mg}, 0.58 \mathrm{mmol})$ was suspended in conc. sulfuric acid $(95 \%, 60 \mathrm{~mL})$. The mixture was kept at $90{ }^{\circ} \mathrm{C}$ for $12 \mathrm{~h}$. The resulting solution was cooled and poured very slowly onto ice. The aqueous phase was extracted twice with $150 \mathrm{~mL}$ each of tert-butyl methyl ether. The organic phases were combined and concentrated to approx. $100 \mathrm{~mL}$ and extracted with aqueous $10 \%$ sodium carbonate. The carbonate phase was acidified slowly with 5 $\mathrm{M}$ hydrochloric acid and extracted four times with $50 \mathrm{~mL}$ each of tert-butyl methyl ether. The organic phases were combined, dried over anhydrous sodium sulfate, filtered, and the solvent removed under vacuum. The residue was dissolved in diethyl ether (approx. $10 \mathrm{~mL}$ ) and the product precipitated by slow addition of $\mathrm{n}$-heptane. This purification step was repeated three times. Yield: approx. $380 \mathrm{mg}(84 \%)$ of a red powder. Mp. $>280{ }^{\circ} \mathrm{C}$. Infrared (IR) (KBr): $\nu=$ 3702-2643, 1703, and $1661 \mathrm{~cm}^{-1}$. MS (ESI): $\mathrm{m} / \mathrm{z} 788.83$ $[\mathrm{M}]^{-}(70 \%), 743.60\left[\mathrm{M}-\mathrm{CO}_{2}\right]^{-}(100 \%), 698.82[\mathrm{M}-$ $\left.2 \mathrm{CO}_{2}\right]^{-}(60 \%)$. HRMS (ESI): calcd. for $\mathrm{C}_{22} \mathrm{H}_{4} \mathrm{Cl}_{12} \mathrm{O}_{6}$ [M $+\mathrm{H}]^{+}$789.618; found 789.618 .

\section{EPR Spectroscopy}

The L-band EPR measurements were carried out using E540 L-Band Bruker ${ }^{\circledR}$ Spectrometer equipped with E 540R23 L-Band EPR-resonator.

Stability measurements in various media were done with simultaneous record of the 7,7,8,8-tetracyanoquinodimethane anion radical (TCNQ) spectrum. The spectral displacement was achieved by applying magnetic field gradient $5 \mathrm{G} / \mathrm{cm}$. The radical amplitudes were measured and normalized by the standard amplitude. The line width measurements were performed with 10,000 points resolution in the field of $2 \mathrm{G}$ around the maximum of the radical absorption signal. Automatic fine tuning after each scan (10 scans, $200 \mathrm{~s}$ each) was enabled. Microwave power was $3.6 \mathrm{~mW}$, frequency $1.09 \mathrm{GHz}$, modulation amplitude 0.01 $\mathrm{G}$, modulation frequency $10 \mathrm{kHz}$. No saturation effects were visible.

The X-band EPR relaxation measurements were performed with Bruker ESP 380 FT/EPR X-band spectrometer in room temperature $\left(23^{\circ} \mathrm{C}\right)$. To estimate the spin-spin $\left(\mathrm{T}_{2 *}\right)$ and spin-lattice $\left(\mathrm{T}_{1}\right)$ relaxation times, free induction decay (FID) sequence was used. Parameters used for $\mathrm{T}_{2}$ * assessment were as followed: pulse $\left(p_{1}\right)$ of $24 \mathrm{~ns}$, delay time $\left(d_{0}\right)$ of $96 \mathrm{~ns}$ and acquisition in steps of $8 \mathrm{~ns}$. Recorded number of points was 128. Parameters for $T_{1}$ assessment from FID were $p_{1}=80 \mathrm{~ns}, d_{1}=96 \mathrm{~ns}$, and the sequence was $\left(p_{1} d_{1}\right)_{8 x} \mathrm{dx}(8 \mathrm{~ns}) p_{0}(24 \mathrm{~ns}) d_{0}(104 \mathrm{~ns})$ and acquisition in steps of $8 \mathrm{~ns}$ [21]. Number of points recorded 256. Attenuation of microwave pulses was set to $5 \mathrm{~dB}$ of the maximal TWT amplifier power. No saturation effects were visible at this power level.

\section{Sensitivity to Oxygen in Liquid Environment}

Simultaneously with the nitrogen gas saturation experiments of the PTMTC $\left(\mathrm{C}_{22} \mathrm{H}_{3} \mathrm{Cl}_{12} \mathrm{O}_{6}{ }^{\circ}, 788.69 \mathrm{~g} / \mathrm{M}\right)$ radical, the EPR spectrum was recorded. The radical was mixed with PBS $(\mathrm{pH}=7.4)$ solution gaining $1 \mathrm{mM}$ of final concentration. The PBS composition was: $\mathrm{NaCl} 8 \mathrm{~g} / \mathrm{L}, \mathrm{KCl} 0.2$ $\mathrm{g} / \mathrm{L}, \mathrm{Na}_{2} \mathrm{HPO}_{4} 1.42 \mathrm{~g} / \mathrm{L}, \mathrm{KH}_{2} \mathrm{PO}_{4} 0.24 \mathrm{~g} / \mathrm{L}$, and $\mathrm{HCl}(29$ $\mathrm{mM} / \mathrm{L}$ ) for $\mathrm{pH}$ adjustment. The solution was boiled, and cooled with simultaneous flushing with $\mathrm{N}_{2}$ multiple times. The EPR experiment started when the PreSense ${ }^{\circledR}$ oximeter with NTH-PSt7-02 oxygen microsensor, submerged in the solution, showed diode saturation value. Salinity correction was applied. The vial was open allowing the mixing of air with the solution. The oximeter measurements were performed simultaneously with the EPR measurements. Oxygen gas used in experiments was of $99.999 \%$ purity grade.

\section{Stability of the Radical in Different Solutions}

The PTMTC was dissolved in multiple solvents (always 1 $\mathrm{mM}$ of radical concentration):

1. Pure PBS buffer $(\mathrm{pH}=7.4)$.

2. Eagle's minimum essential medium (EMEM) for cell culture $(1 \mathrm{~mL})$ supplemented with $10 \%$ of fetal bovine serum (FBS), $1 \%$ antibiotic (penicillin $100 \mu \mathrm{g} / \mathrm{mL}$, streptomycin $100 \mu \mathrm{g} / \mathrm{mL}$, and $\mathrm{P} / \mathrm{S}$ ) and $250 \mu \mathrm{L}$ of PBS $(\mathrm{pH}=7.4)$ buffer.

3. McCoy's cell culture medium $(1 \mathrm{~mL})$ supplemented with $10 \%$ of FBS, $1 \%$ antibiotic (P/S) and $250 \mu \mathrm{L}$ of PBS ( $\mathrm{pH}=7.4$ ) buffer.

4. Solution of full rat heart blood $(750 \mu \mathrm{L})$ mixed with PBS buffer $(250 \mu \mathrm{L}, \mathrm{pH}=7.4)$.

5. Solution of rat blood plasma $(750 \mu \mathrm{L})$ mixed with PBS buffer $(250 \mu \mathrm{L}, \mathrm{pH}=7.4)$ and stored 4 days in $5^{\circ} \mathrm{C}$ before the use.

\section{Fluorescence Spectroscopy}

Fluorescence emission of freshly prepared $1.16 \mathrm{mM}$ PTMTC radical solution samples in PBS $(\mathrm{pH}=7.4)$ was 
measured in the range of $500-850 \mathrm{~nm}$ and at different excitation wavelengths from 320 to $480 \mathrm{~nm}$. The spectra were recorded on the Gilden Photonics FluoroSENS 9000 spectrometer equipped with $150 \mathrm{~W}$ continuous Xenon Arc Lamp (Ozone Free, Osram XBO 150 W/CR OFR). As a background reference, the emission of the pure PBS buffer was measured.

\section{Cytotoxicity Tests}

A human colorectal adenocarcinoma cell line (HT-29, ATCC ${ }^{\circledR}$ HTB- $38^{\text {TM }}$ ) and pharynx squamous cell carcinoma ( $\mathrm{FaDu}, \mathrm{ATCC}^{\circledR} \mathrm{HTB}^{\circledR} 43^{\mathrm{TM}}$ ) were maintained in EMEM (for HT-29 cells) and McCoy's (for FaDu cells), supplemented with $10 \%$ of FBS and $1 \%$ of antibiotics (penicillin $100 \mu \mathrm{g}$ / $\mathrm{mL}$, streptomycin $100 \mu \mathrm{g} / \mathrm{mL}$ ) at $37^{\circ} \mathrm{C}$ and $5 \% \mathrm{CO}_{2}$. For exposure, cells were cultured in 96-well plates. After $24 \mathrm{~h}$ cells were exposed to PTMTC solutions in complete medium $(2.5,1.25$, and $0.625 \mathrm{mM})$ for 24,48 , and $72 \mathrm{~h}$. After exposure time, WST-1 assay (Premix WST-1 Cell Proliferation Assay System; Takara, Clontech) were performed according to the producers' procedure. Briefly, $10 \mu \mathrm{L}$ of Premix WST-1 Cell Proliferation Assay System Reagent were added into each wells, then after $2-4 \mathrm{~h}$ the absorbance at wavelength $450 \mathrm{~nm}$ were read (ref. wavelength $620 \mathrm{~nm}$ ).

Cell exposure experiments were carried out in duplicates with positive (without PTMTC) and negative (DMSO) control.

\section{The Uptake of PTMTC and Interference with Luciferin-Luciferase-Based Assays}

The human prostate adeniocarcinoma LNCaP cells were stably transfected with a luciferase reporter gene as previously described [22]. The cells were seeded in $2.5 \mathrm{~cm}$ Petri dishes at density $0.5 \times 10^{6}$ cells per dish at allowed to attach overnight. Subsequently the dishes were washed twice with PBS and PTMTC (stock concentration $10 \mathrm{mM}$ in PBS) was added at concentrations $1 \mathrm{mM}$ and incubated for 2 and $6 \mathrm{~h}$. After the incubation the medium was removed, the cells were washed with PBS and fresh medium containing $150 \mu \mathrm{g} / \mathrm{mL}$ luciferine was added to the dishes. The luminescence and fluorescence (excitation at $465 \mathrm{~nm}$, emission at $720 \mathrm{~nm}$ ) was measured using IVIS Spectrum (Caliper Life Sciences, Hopkington, MA, USA).

\section{In vitro Confocal Studies}

HT-29 cell were seeded into LabTech, after $24 \mathrm{~h}$ medium was washed out and PTMTC (concentration of $2.5 \mathrm{mM}$ ) was added and incubated for $24 \mathrm{~h}$ at $37^{\circ} \mathrm{C}$ and $5 \% \mathrm{CO}_{2}$ content in humid atmosphere. Then PTMTC was washed out and cells were fixed (4\% paraformaldehyde in PBS at $37^{\circ} \mathrm{C}$ for $15 \mathrm{~min}, 0.2 \%$ Triton $\mathrm{X}-100$ for $5 \mathrm{~min}$ ) and stained with concanavalin A, Alexa Fluor 647 Conjugate (Con A, Molecular Probes, the working concentration: $100 \mu \mathrm{g} / \mathrm{mL}$ ). Confocal imaging was carried out using the Zeiss LSM 780 system.

\section{In vivo Toxicity Testing}

The experiment was performed according to the procedure OECD 420 [23], with permission obtained from Local Ethical Committee prior to the experiment. The tested compound was dissolved in PBS and administered to three female BALB/c mice intraperitoneally and to three female $\mathrm{BALB} / \mathrm{c}$ mice intravenously (into the tail vein). The control animals received vehicle alone. The animals were observed for three days for symptoms of distress and pain according to generally accepted recommendations Carstens and Moberg [24]. Three days after administration of tested compound animals were sacrificed and blood samples were collected for further biochemical analyzes. The activities of the liver enzymes such as alanine aminotransferase (AlAT), asparagine aminotransferase (AsPAT), alkaline phosphatase (ALP), and lactate dehydrogenase (LDH) were measured using kits ordered from Pointe Scientific (Canton, MI USA) according to the manufacturer's recommendations.

\section{Statistics}

Statistical analysis was performed using GraphPad Prism ${ }^{\mathrm{TM}}$ 5.00 software (GraphPad Software, San Diego, USA). Results were expressed as means \pm SD. Differences with a $p$-value $<0.05$ were considered to be statistically significant.

\section{Results}

\section{EPR Spectroscopy}

The molecular structure was firstly optimized by DFT methods, to show the ground state molecular shape. The structure depicted in Fig. 1 was optimized using unrestricted ground state calculations with the b3lyp/6-311 $++\mathrm{g}(\mathrm{d}, \mathrm{p})$ basis set, without additional solvation model. The molecule exhibits $\mathrm{C}_{3}$ symmetry, where the normal to four central carbon atoms $(1 \mathrm{C}, 7 \mathrm{C}, 13 \mathrm{C}$, and $19 \mathrm{C}$ atoms) and the normal to the aryl group plane form an angle of around $45^{\circ}$. The normal to the $-\mathrm{COOH}$ plane (e.g., $43 \mathrm{H}, 42 \mathrm{O}, 41 \mathrm{O}$, and $40 \mathrm{C}$ atoms) is rotated by $90^{\circ}$ to the aryl plane (Fig. 2).

The EPR signal in solution (PBS pH 7.4) shows a radical $S=1 / 2$ which interacts with multiple nuclei of carbon isotope ${ }^{13} \mathrm{C}$ giving rise to multiple hyper- $\left(\mathrm{a}_{4} 13.08 \mathrm{G}\right)$ and super-hyperfine structure transitions $\left(\operatorname{shfs}\left(a_{3}, a_{2}\right.\right.$, and $\left.a_{1}\right)$ 
Fig. 1 Molecular structure of PTMTC optimized in Gaussian visualized in GaussView (gray $\mathrm{C}$, green $\mathrm{Cl}$, red $\mathrm{O}$, and white $\mathrm{H}$ ) [30]. Inset shows radial distance through space from the center $\mathrm{C}$ atom with sources of isotropic shfs (color figure online)

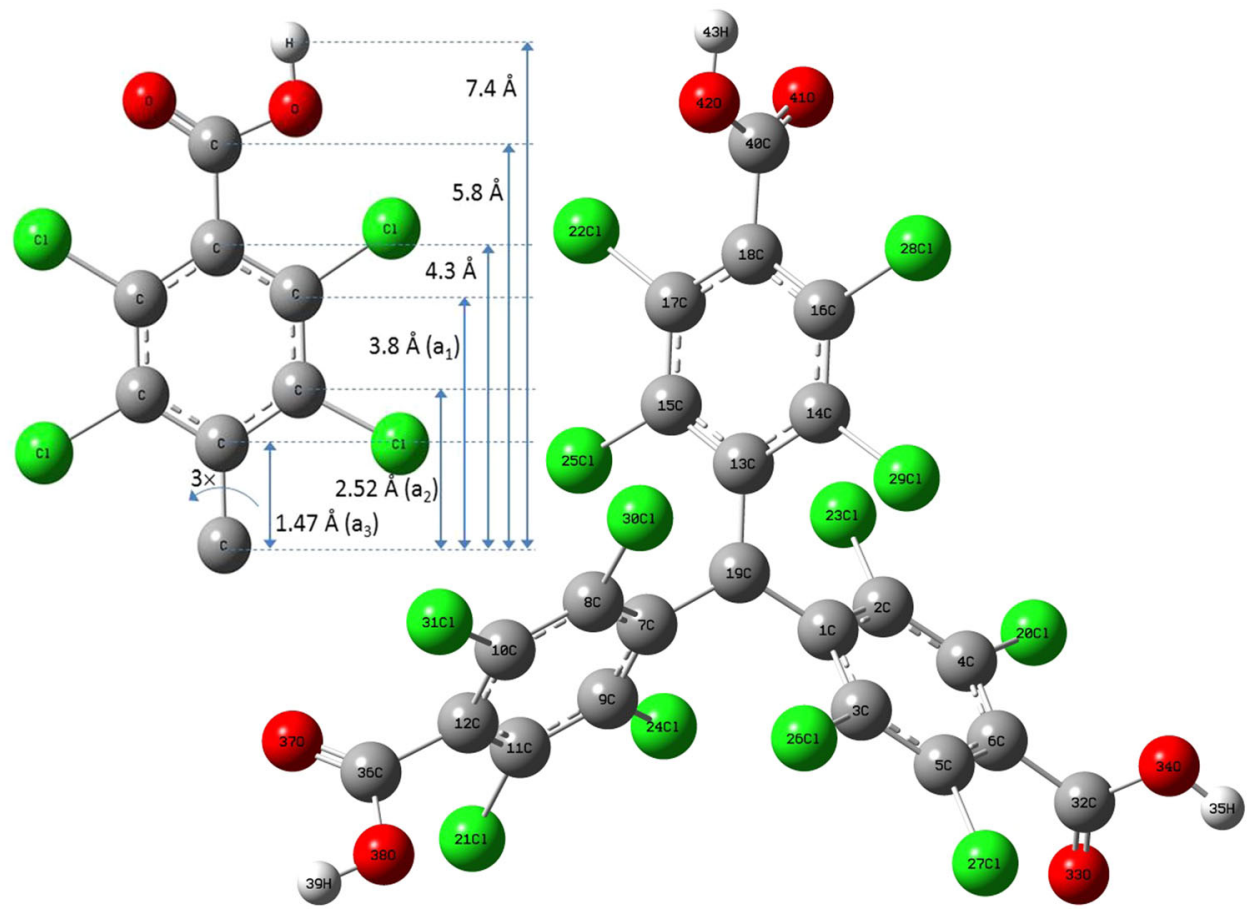

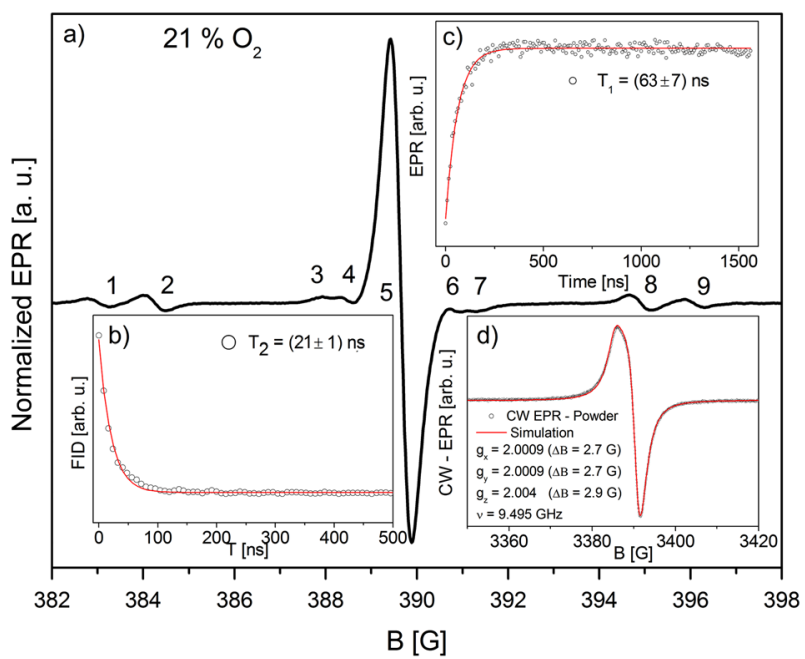

Fig. 2 a EPR signal of PTMTC in PBS solution pH $7.4\left(\sim 18.5 \% \mathrm{O}_{2}\right)$ inset: b free induction decay $\left(T_{2}^{*}=(21 \pm 1) \mathrm{ns}\right)$; c $T_{1}=(63 \pm 7) \mathrm{ns}$ (from FID—saturation); d powder EPR line and simulation

Fig. 1; Table 1). Other nuclei having unpaired nuclear spins in the system are: ${ }^{1} \mathrm{H},{ }^{35} \mathrm{Cl}$, and ${ }^{37} \mathrm{Cl}$, but their distance from the central atom or the abundance disqualifies them as the source of the super hyperfine coupling. An additional field sweep $(100 \mathrm{G})$ with multiple accumulations was made and no further shfs were found.

The EPR relaxation measurements were assessed at room temperature $\left(23^{\circ} \mathrm{C}\right)$. The spin-spin relaxation time $T_{2}{ }^{*}=$ $(21 \pm 1) \mathrm{ns}$ and spin-lattice relaxation time $T_{1}=(63 \pm 7) \mathrm{ns}$ were obtained from saturation recovery of FID. It was impossible to assess an electron spin echo, which means the line was homogeneously broadened. Short electron spin relaxation times do not encourage the use of this probe in pulse EPR imaging experiments [25, 26]. The powder spectrum shows an axial g-tensor with values $g_{x}=g_{y}=$ 2.0009, and $g_{z}=2.004$ which correspond to linewidths $\Delta \mathrm{B}_{x}=2.7 \mathrm{G}, \Delta \mathrm{B}_{y}=2.7 \mathrm{G}, \Delta \mathrm{B}_{z}=2.9 \mathrm{G}$.

\section{Sensitivity to Oxygen in Liquid Environment (PBS pH 7.4)}

The measurement of the EPR line width started after the PBS solution had been saturated with $\mathrm{N}_{2}$ gas. Oxygen content was out of the measurement range of the PreSense ${ }^{\circledR}$ oximeter. The lowest line width observed for the central signal was $0.39 \mathrm{G}$ which in Fig. 3 was assigned to $0 \% \mathrm{pO}_{2}$. After the first measurement free exchange with air through the surface was allowed. The measurements took $24 \mathrm{~h}$ in total reaching the initial value of $18.5 \% \mathrm{O}_{2}$. The line width dependence vs. oxygenation can be approximated by the equation $\Delta \mathrm{B} \quad[\mathrm{G}]=0.0148 \quad\left( \pm 10^{-4}\right) \quad \mathrm{pO}_{2}[\%]+0.395$ $\left( \pm 10^{-2}\right)$, in the range of $0-18.5 \%$ of $\mathrm{pO}_{2}$. Using chemical methods of deoxygenation (saturation with $\mathrm{Na}_{2} \mathrm{SO}_{3}$ powder), a line width of $0.37 \mathrm{G}$ was achieved. The maximal line width observed after $\mathrm{O}_{2}$ saturation was $0.79 \mathrm{G}$ (Fig. 3).

\section{Stability of the Radical in Different Solutions}

The radical showed different temporal behavior dependent on solution used (Table 2). Maximum stability was observed in PBS solution where the signal amplitude 
Table 1 Isotropic hyper- and super hyperfine coupling constants $(\nu=1.09 \mathrm{GHz}, 18.5 \%$ $\left.\mathrm{O}_{2}\right)$

\begin{tabular}{llllllllll}
\hline No. & 1 & 2 & 3 & 4 & 5 & 6 & 7 & 8 & 9 \\
\hline B [G] & 382.63 & 383.95 & 388.00 & 388.46 & 389.60 & 390.78 & 391.29 & 394.61 & 395.76 \\
$\Delta \mathrm{B}[\mathrm{G}]$ & 0.46 & 0.46 & 0.21 & 0.22 & 0.47 & 0.22 & 0.21 & 0.46 & 0.46 \\
A [a. u.] & 0.016 & 0.030 & 0.0022 & 0.0075 & 1 & 0.0075 & 0.0022 & 0.030 & 0.016 \\
I [a. u.] & 0.0034 & 0.0063 & $97 \times 10^{-6}$ & 0.00036 & 0.22 & 0.00036 & $97 \times 10^{-6}$ & 0.0063 & 0.0034 \\
a $_{1}$ [G] & & & & 2.32 & & & & & \\
a $_{2}$ [G] & & & 3.29 & & & & & & \\
a $_{3}$ [G] & & 10.66 & & & & & & & \\
$a_{4}[\mathrm{G}]$ & 13.08 & & & & & & & & \\
\hline
\end{tabular}

No. is the number of line in the Fig. 2, B is the field where the signal appears, $\Delta \mathrm{B}$ is the peak-peak linewidth, $A$ is the amplitude, $I$ is the intensity from equation $I=A \cdot \Delta B^{2}[31], \mathrm{a}_{\mathrm{i}}$ is the isotropic Fermi coupling constants. For the assignment of couplings No. $1-9$ to ${ }^{13} \mathrm{C}$ atoms in PTMTC, see [32]

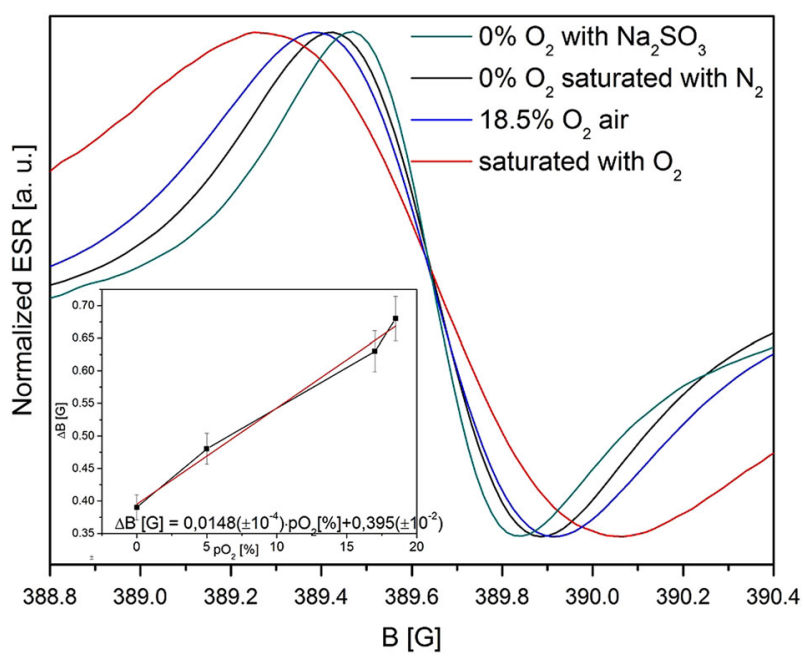

Fig. 3 Central line broadening of the main EPR line component; (inset) linewidth vs. saturation with oxygen in PBS pH 7.4

decreased linearly with time and after $93.5 \mathrm{~h}$ ended at $97 \%$ of the initial amplitude. The radical signal in the second and third solution behaved similarly, decrease starting after $48 \mathrm{~h}$ and reaching $94 \%$ after $93.5 \mathrm{~h}$. The strongest decrease, which started immediately, was observed in the full blood sample where the signal had completely disappeared after $72 \mathrm{~h}$. The solution with only plasma did not show this behavior but it is important to mention that before measurement the plasma was stored at $5{ }^{\circ} \mathrm{C}$ for 4 days before use. Stronger temporal changes may occur with a fresh sample. No differences in the EPR signal were observed when EDTA as anticoagulant was used instead of heparin.

The behavior of the sample in PBS solution was also tested after a longer storage at light conditions. The color of the PTMTC solution changed under the influence of light from red to yellow (Fig. 4). The difference was visible in the UV-Vis spectrum, where two strong lines at 363.2 and $380.0 \mathrm{~nm}$ vanished and the line at $494.0 \mathrm{~nm}$ became more dominant. This most likely was caused by the process of oxidative decarboxylation described by Decroos [27].
Table 2 Stability of the radical in different solutions

\begin{tabular}{lllllll}
\hline $\begin{array}{l}\text { Time } \\
\text { Solvent }\end{array}$ & & 0 (h) & 24 & 48 & 72 & 93.5 \\
$\%$ & $\%$ & $\%$ & $\%$ & $\%$ \\
\hline 1 & PBS buffer pH $=7.4$ & 100 & 99 & 99 & 98 & 97 \\
$\mathbf{2}$ & $\begin{array}{l}\text { EMEM FBS 10\% P/S 1\% } \\
(0.75 \mathrm{~mL})+\text { PBS }(0.25 \mathrm{~mL})\end{array}$ & 100 & 100 & 100 & 94 & 94 \\
3 & $\begin{array}{l}\text { McCoy's FBS 10\% P/S 1\% } \\
(0.75 \mathrm{~mL})+\text { PBS }(0.25 \mathrm{~mL})\end{array}$ & 100 & 100 & 100 & 94 & 94 \\
4 & $\begin{array}{l}\text { Rat blood + heparin }(0.75 \\
\text { mL })+ \text { PBS }(0.25 \mathrm{~mL})\end{array}$ & 100 & 64 & 34 & 1.3 & 0 \\
5 & $\begin{array}{l}\text { Blood plasma }+ \text { heparin } \\
(0.75 \mathrm{~mL})+\text { PBS }(0.25 \mathrm{~mL})\end{array}$ & 100 & 100 & 100 & 100 & 100 \\
\hline
\end{tabular}

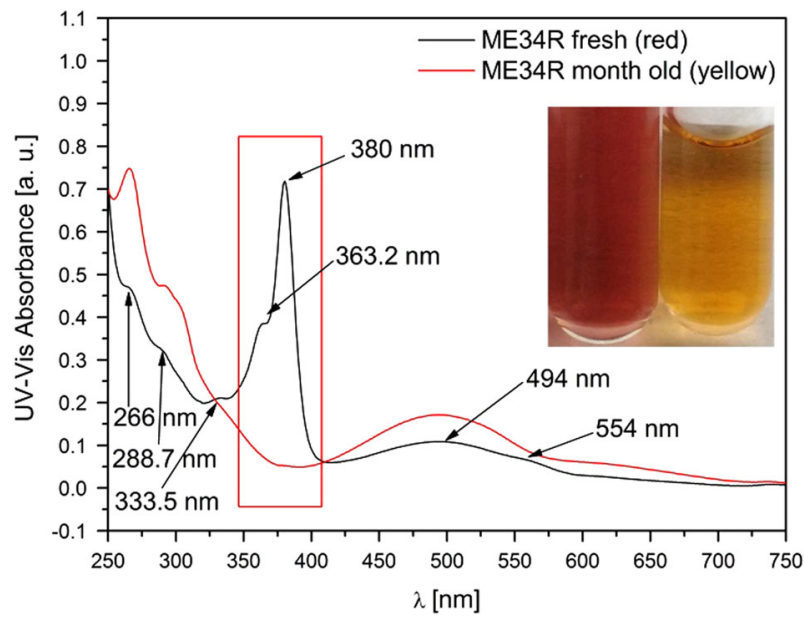

Fig. 4 UV-Vis spectra of fresh and month old samples held under natural light conditions

\section{Fluorescence Spectroscopy}

A PTMTC radical solution sample on excitation at $410 \mathrm{~nm}$ exhibited the strongest fluorescence emission peak with the maximum at $632 \mathrm{~nm}$ (linewidth at half height was $115 \mathrm{~nm}$ ), 
with a Stokes shift of $1.06 \mathrm{eV}$ (Fig. 5). Upon different excitation wavelength the fluorescence emission peak position did not change, however the intensity significantly varied. The pure PBS solution showed weak fluorescence, which vanished in the background. The ratio of counts at $632 \mathrm{~nm}$ for PTMTC radical solution and pure PBS sample was around $1574\left(2.675 \times 10^{6} / 1700\right)$. As an important index, the fluorescent quantum yield (QY) of PTMTC radical solution $(14.2 \mu \mathrm{M})$ in PBS was determined by applying the following equation:

$\mathrm{QY}_{\text {sample }}=\mathrm{QY}_{\mathrm{st}}\left(\frac{I_{\text {sample }}}{I_{\mathrm{st}}}\right)\left(\frac{n_{\text {sample }}^{2}}{n_{\mathrm{st}}^{2}}\right)\left(\frac{A_{\mathrm{st}}}{A_{\text {sample }}}\right)$,

where QY is the quantum yield, $I$ is the measured integrated emission at the excitation wavelength $488 \mathrm{~nm}, A$ is the absorbance at the excitation wavelength $488 \mathrm{~nm}, n$ the refractive index of the solvent. Rhodamine $6 \mathrm{G}$ solution in ethanol served as standard $(\mathrm{QY}=95 \%)$. In order to minimize the reabsorption effect, the absorbance of rhodamine standard and radical solution was kept below 0.1 at $488 \mathrm{~nm}$ excitation wavelengths. The fluorescence quantum yield of the PTMTC radical solution in PBS was calculated to be $5.7 \%$. This is a very low QY when comparing to standard fluorescence dyes such as Rhodamine $6 \mathrm{G}$ with QY of $94 \%$, quinine sulfate (57.7\%) and zinc phthalocyanine (30\%). On the other hand, there are organic fluorescent dyes with similarly low QY e.g., chlorophyll $b(7.4 \%)$. Also currently intensively investigated inorganic quantum dots do not reach high QY values, and yet they are successfully applied as fluorescent markers, e.g., dodecanethiol-capped CuInZn $_{x} \mathrm{~S}_{2+x}$ (25\%) [28] or un-modified CdSeTe QDs (7.6\%) [29].

Figure $5 \mathrm{c}$ shows the maximum fluorescence count vs. the excitation wavelength and energy. The most efficient radiant relaxation process appears for excitation energy of

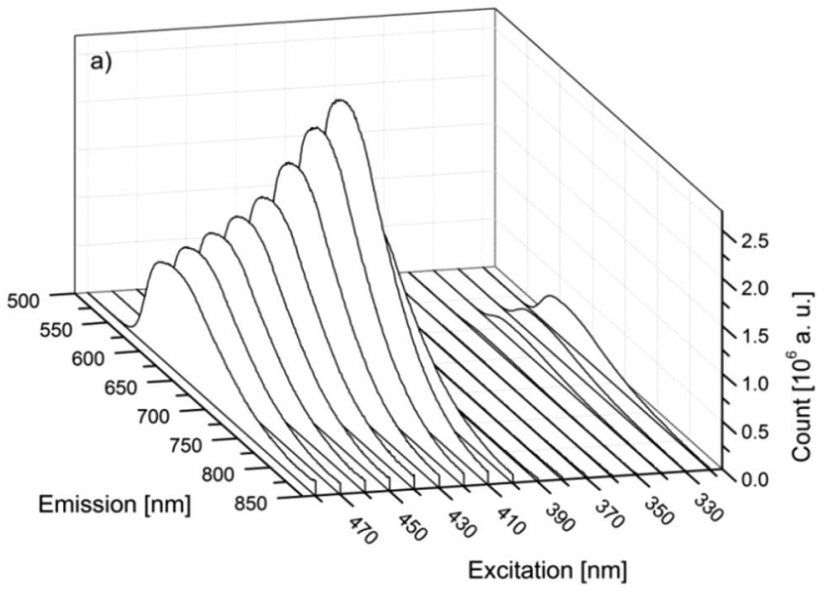

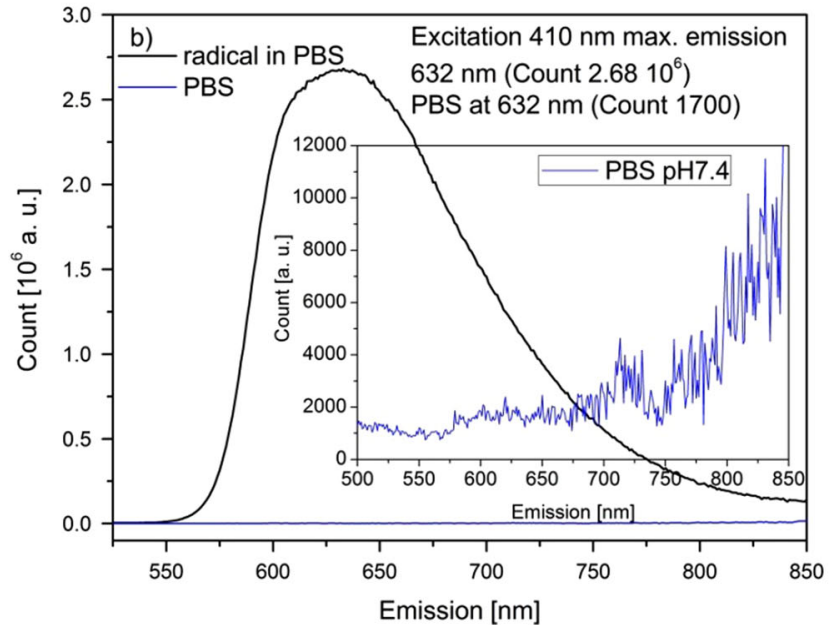

Fig. 5 a Fluorescence vs. multiple excitation wavelengths; b The strongest fluorescence for the excitation at $410 \mathrm{~nm}$ (black) and PBS fluorescence (blue); inset shows fluorescence of PBS pH 7.4 buffer in

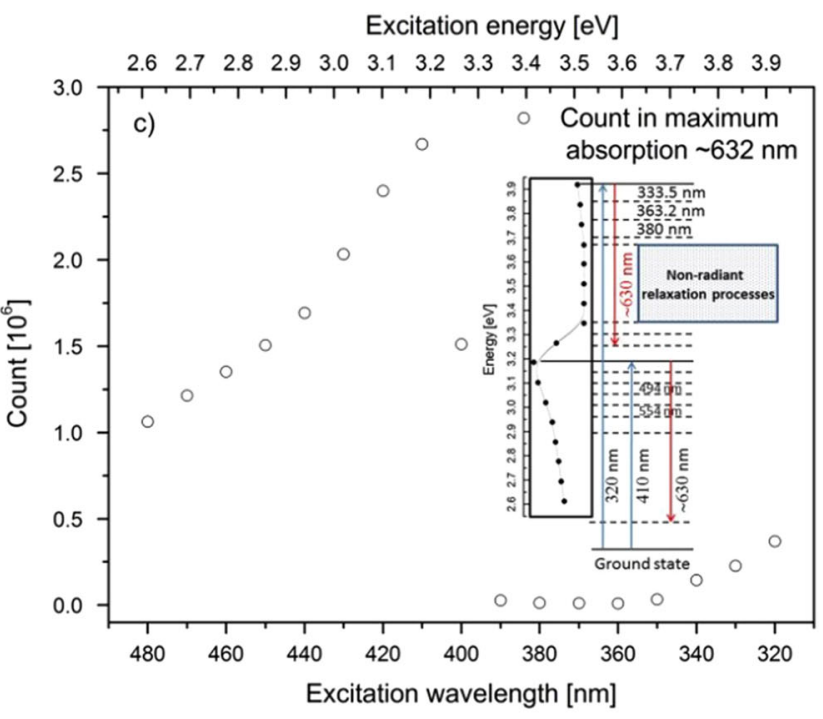

larger scale; c Count in maximum absorption $\sim 632 \mathrm{~nm}$ vs. excitation wavelength, inset shows proposed Jablonski diagram for this system (not in scale) (color figure online) 
around $3.024 \mathrm{eV}(410 \mathrm{~nm})$. Red arrows indicate radiant relaxation process found in the fluorescence plot. Additional absorption levels are indicated from absorbance studies. As it seems non-radiant relaxation processes dominates in the range of $3.18 \mathrm{eV}(390 \mathrm{~nm})$ to $3.54 \mathrm{eV}(350 \mathrm{~nm})$, where the fluorescence count drops to a level of approx. 20,000. It rises again at the highest excitation energies used. Nonradiant relaxation processes could occur here in the form of vibrations (oscillations) of single or multiphonon transitions.

\section{Cytotoxicity}

After exposing HT-29 and FaDu cells to PTMTC, the cell viability was measured. It was observed that viability of HT-29 was high and stable, even at the highest dose (2.5 $\mathrm{mM}$ ) and at the longest time of incubation (72 h) (Fig. 6a). The viability of $\mathrm{FaDu}$ cells after $24 \mathrm{~h}$ of incubation decreased with increasing PTMTC concentrations, and reached 73,58 , and $56 \%$ at concentrations of $0.625,1.25$, and $2.5 \mathrm{mM}$, respectively. After 48 and $72 \mathrm{~h}$ the same behavior of cellular response was observed (Fig. 6b).

\section{Cellular Uptake and Interaction with Luciferase-Luciferin Assay}

The uptake and luciferase-luciferin assays were performed using the IVIS Spectrum system, which allows simultaneous measurement of both luminescence and fluorescence. The excitation and emission filters were selected experimentally to measure the fluorescence of PTMTC and exclude autofluorescence background of the cells itself. The experiment showed that PTMTC was not absorbed by cells and its presence had no impact on the fluorescence intensity produced by oxidation of luciferin in luciferase expressing LNCaP cells (data not shown).

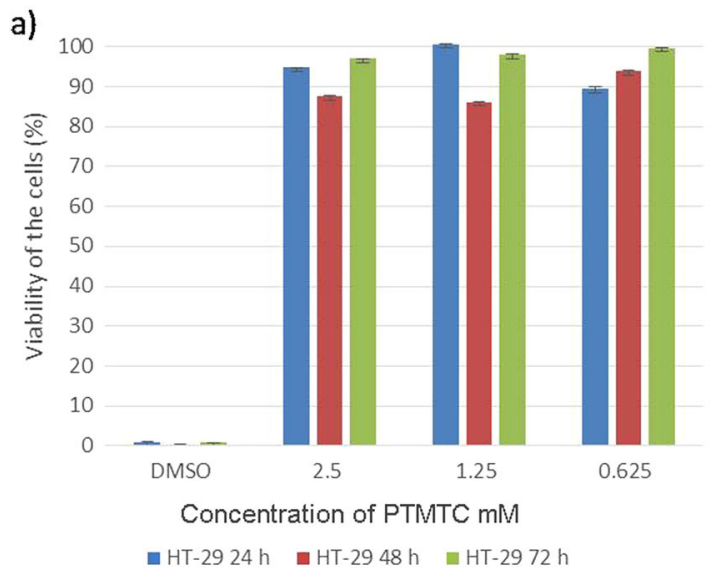

\section{In vitro Confocal Studies}

In order to unequivocally identify the fluorescent species, the images of the cell and of a PTMTC suspension were taken in the lambda mode with excitation at $405 \mathrm{~nm}$, thus obtaining spectra in the range of $560-685 \mathrm{~nm}$ for every pixel in the images (Fig. 7). The black squares in Fig. 7 represent a typical spectrum of the cell stained with concanavaline A. Red circles refer to the spectrum of PTMTC suspension measured at the concentration used during the incubation $(2.5 \mathrm{mM})$ and with the same imaging parameters. The use of the lambda mode allows for easy spectral separation of the signals from PTMTC and from concanavaline A. Fluorescence of PTMTC could be easily detected in the range of 560-620 $\mathrm{nm}$ where the contribution of concanavaline A is negligible. Fluorescence of PTMTC, if present, could be easily detected in the range of 560-620

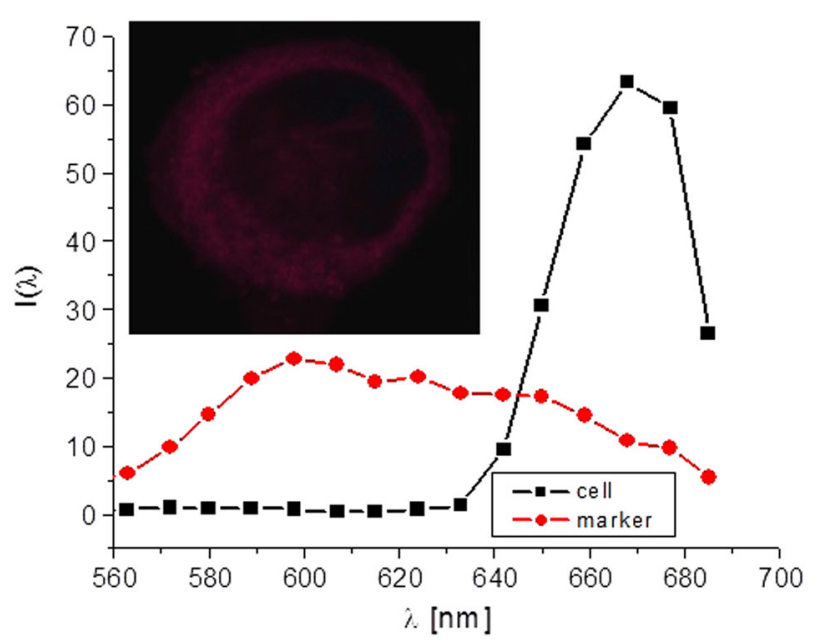

Fig. 7 Emission spectra of the membrane of HT-29 cell incubated with PTMTC for $24 \mathrm{~h}$ and stained with concanavaline A (black squares) and of the PTMTC suspension in medium (red circles). Inset: LSM image of a HT-29 cell taken in the lambda mode

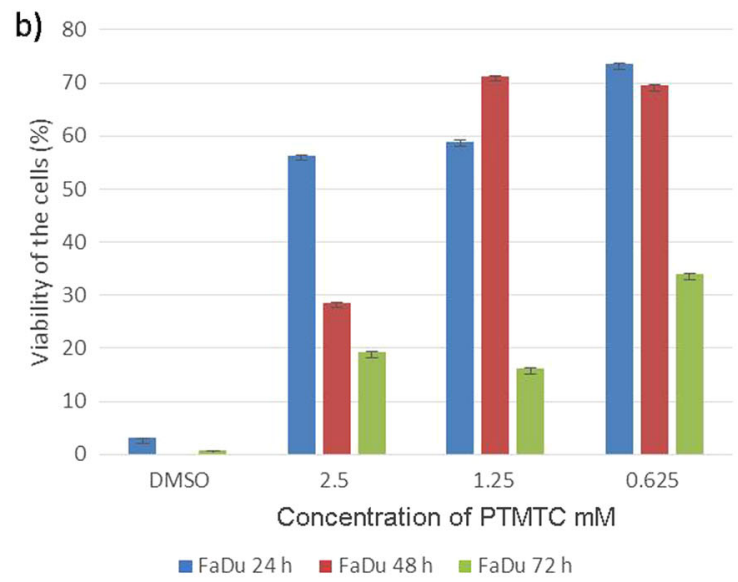

Fig. 6 Viability of HT-29 (a) and FaDu (b) cell lines after 24, 48, and $72 \mathrm{~h}$ of incubation with PTMTC 


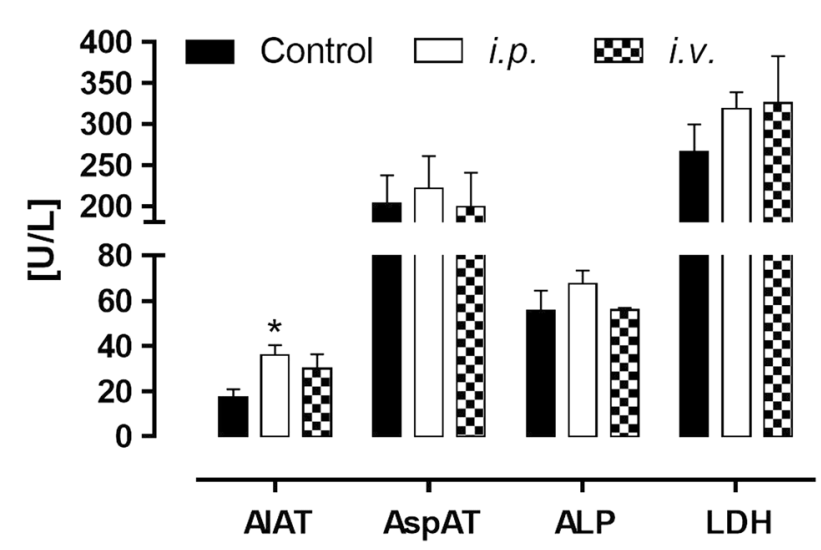

Fig. 8 Effect of PTMTC on activity of AlAT, AspAT, ALP, and LDH 3 days after i.p. and i.v. administration of tested compound at dose $250 \mu \mathrm{g} / \mathrm{kg} \mathrm{BW}$. *Significantly different from control, $p<0.05$

$\mathrm{nm}$ where the contribution of concanavaline A emission is negligible. The main result of this measurement is that no such contribution of PTMTC fluorescence in the images of the cells incubated with this compound could be detected. (Fig. 8)

\section{In vivo Acute Toxicity Test}

After administration of tested compound via both i.p. and i.v. routes, animals did not show any signs of pain or distress. Their behavior, motoric activity, food and water intake did not differ from the control group. After 3 days, the animals were sacrificed and their livers and kidneys were examined: no macroscopically visible lesions were found. In blood samples a significant increase of AlAT was measured in mice receiving PTMTC via intraperitoneal injection. The activity of other enzymes in both tested groups was slightly increased, however these changes were not significant.

\section{Conclusions}

The EPR spectrum of PTMTC was recorded in an L-band spectrometer and analyzed. The signal of the radical displayed four different hyper and super-hyperfine coupling constants of different intensities which were assigned to interactions of the electron spin with ${ }^{13} \mathrm{C}$ nuclei. Relaxation times of PTMTC in PBS, namely $T_{2}{ }^{*}$ of $(21 \pm 1)$ ns and $T_{1}$ of $(63 \pm 7) \mathrm{ns}$, were obtained from saturation recovery of the FID. The linewidth sensitivity to $\mathrm{O}_{2}$ concentration was estimated. The temporal stability of the compound was tested in PBS, cell medium, full rat blood, and blood plasma. The molecule is stable in PBS solution, but decomposes immediately in blood. However, this does not prevent to use the PTMTC for in vivo studies. Therefore, the fluorescence properties of this marker were preliminarily investigated. The fluorescence quantum yield of the PTMTC radical solution in PBS was calculated to be 5.7\%, which was rather low, but allows attempts to use this radical as a bimodal EPR/fluorescence imaging marker. In vitro time-dependent and dose-dependent cytotoxicity studies revealed the low toxicity of PTMTC against HT-29 and FaDu cell lines. Further tests showed that the compound was not absorbed by cancer cells and did not interfere with luciferin-luciferase based assays. PTMTC was also tested in vivo. It was administered to Balb/c mice at $250 \mathrm{mg} / \mathrm{kg}$ BW via both i.v. and i.p. administration. The radical caused only slight but statistically significant elevation of alanine aminotransferase in the i.p. group, while levels of AsPAT, ALP, and LDH remained unchanged. Mice receiving PTMTC after 3 days did not exhibit any signs of pain or distress nor did we notice any differences in food and water intake between control and test groups. The poor stability of PTMTC in blood indicates that it will not be stable in vivo for 3 days. However, such long-term stability is not needed for the planned combined EPR-fluoresence imaging, but it was important to show PTMTC did not interfere negatively with the host physiology.

In summary, PTMTC is a non-toxic oxygen sensor exhibiting fluorescent properties. Thereby, it is a perfect candidate for multimodal imaging with the prospect of quantitative information about oxygenation of the tissue (EPR) and distribution of the marker in the body (fluorescence).

Acknowledgements This work was partially supported from National Science Center, (UMO-2014/15/B/ST4/04946 and UMO2014/15/B/NZ5/01488). We are especially thankful for the assistance during the chemical preparations to dr Marta Woźniak-Budych from NanoBioMedical Center, UAM.

\section{Compliance with Ethical Standards}

Conflict of Interest The authors declare that they have no competing interests.

Open Access This article is distributed under the terms of the Creative Commons Attribution 4.0 International License (http://crea tivecommons.org/licenses/by/4.0/), which permits unrestricted use, distribution, and reproduction in any medium, provided you give appropriate credit to the original author(s) and the source, provide a link to the Creative Commons license, and indicate if changes were made.

\section{References}

1. Nathan, A. T., \& Singer, M. (1999). The oxygen trail: Tissue oxygenation. British Medical Bulletin, 55(1), 96-108.

2. Zielonka, T. M. (2003). Angiogenesis-part I. Mechanism of neovascularization. Alergia Astma Ammunologia, 8(4), 169-174. 
3. Biesaga, B., \& Adamczyk, A. (2004). Znaczenie cech biologicznych guza dla jednoczesnej chemio radioterapii nowotworów złośliwych. Nowotwory Journal of Oncology, 54(2), 135-142.

4. Stone, H. B., Brown, J. M., Phillips, T. L., \& Sutherland, R. M. (1993). Oxygen in human tumors: correlations between methods of measurement and response to therapy. Radiation Research, 136, 422-434.

5. Tannock, I. F., et al. (2005). The scientific basis of radiotherapy. In R. P. Hill \& R. G. Bristow ed, The basic science of oncology (pp. 289-321). New York, NY: McGraw-Hill, Medical Publishing Division.

6. Joiner, M. C., \& van der Kogel, A. (2009). Basic clinical radiobiology (4th ed.). CRC Press, New York: Oxford University Press, London.

7. Zips, D., Zöphel, K., Abolmaali, N., Perrin, R., Abramyuk, A., Haase, R., Appold, S., Steinbach, J., Kotzerke, J., \& Baumann, M. (2012). Exploratory prospective trial of hypoxia-specific PET imaging during radiochemotherapy in patients with locally advanced head-and-neck cancer. Radiotherapy \& Oncology, 105 (1), 21-28.

8. Yu, J. X., Hallac, R. R., Chiguru, S., \& Mason, R. P. (2013). New frontiers and developing applications in 19F NMR. Progress in Nuclear Magnetic Resonance Spectroscopy, 70, 25-49.

9. Gallez, B., Baudelet, C., \& Jordan, B. F. (2004). Assessment of tumor oxygenation by electron paramagnetic resonance: Principles and applications. NMR in Biomedicine, 17, 240-262.

10. Weaver, J., Yang, Y., Purvis, R., Weatherwax, T., Rosen, G. M., \& Liu, K. J. (2014). In vivo evidence of methamphetamine induced attenuation of brain tissue oxygenation as measured by EPR oximetry. Toxicology and Applied Pharmacology, 275, 73-78.

11. Krishna, M. C., English, S., Yamada, K., Yoo, J., Murugesan, R., Devasahayam, N., Cook, J. A., Golman, K., Ardenkjaer-Larsen, J. H., Subramanian, S., \& Mitchell, J. B. (2002). Overhauser enhanced magnetic resonance imaging for tumor oximetry: Coregistration of tumor anatomy and tissue oxygen concentration. Proceedings of the National Academy of Sciences of the United States of America, 99, 2216-2221.

12. Brurberg, K. G., Benjaminsen, I. C., Dørum, L. M., \& Rofstad, E. K. (2007). Fluctuations in tumor blood perfusion assessed by dynamic contrast-enhanced MRI. Magnetic Resonance in Medicine, 58, 473-481.

13. Nielsen, T., Nielsen, N. C., Holm, T. H., Ostergaard, L., Horsman, M. R., \& Busk, M. (2013). Ultra-high field 1H magnetic resonance imaging approaches for acute hypoxia. Acta Oncologica, $52,1287-1292$.

14. Fleming, I. N., Manavaki, R., Blower, P. J., West, C., Williams, K. J., Harris, A. L., Domarkas, J., Lord, S., Baldry, C., \& Gilbert, F. J. (2015). Imaging tumor hypoxia with positron emission tomography. British Journal of Cancer, 112, 238-250.

15. Swartz, H. M., \& Glockner, J. F. (1991). In G. R. Eaton, S. S. Eator \& K. Ohno, (Ed.), EPR imaging and in vivo EPR(pp. 261-290). Boca Raton, FL: CRC Press, Inc.

16. Ardenkjaer-Larsen, J. H., Laursen, I., Leunbach, I., Ehnholm, G., Wistrand, L. G., Petersson, J. S., \& Golman, K. (1998). EPR and DNP properties of certain novel single electron contrast agents intended for oximetric imaging. Journal of Magnetic Resonance, 133(1), 1-12.

17. Golman, K., Petersson, J. S., Ardenkjær-Larsen, J.-H., Leunbach, I., Wistrand, L.-G., Ehnholm, G., \& Liu, K. (2000). Dynamic in vivo oxymetry using overhauser enhanced MR imaging. Journal of Magnetic Resonance, 12, 929-938.

18. Lewis, G. N., Lipkin, D. and Magel, T. T. (1944). The light absorption and fluorescence of triarylmethyl free radicals. Journal of the American Chemical Society, 66(9), 1579-1583.

19. Roques, N., Maspoch, D., Wurst, K., Ruiz-Molina, D., Rovira, C., \& Veciana, J. (2006). Three-dimensional six-connecting organic building blocks based on polychlorotriphenylmethyl unitssynthesis, self-assembly, and magnetic properties. Chemistry-A European Journal, 12, 9238-9253.

20. Frank, J., Elewa, M., Said, M. M., El Shihawy, H. H., El-Sadek, M., Müller, D., Meister, A., Hause, G., Drescher, S., Metz, H., Imming, P., \& Mäder, K. (2015). Synthesis, characterization, and nanoencapsulation of tetrathiatriarylmethyl and tetrachlorotriarylmethyl (Trityl) radical derivatives-a study to advance their applicability as in vivo EPR oxygen sensors. The Journal of Organic Chemistry, 80, 6754-6766.

21. Augustyniak-Jabłokow, M. A., Tadyszak, K., Maćkowiak, M., \& Lijewski, S. (2013). ESR study of spin relaxation in graphene. Chemical Physics Letters, 557, 118-122.

22. Mikuła-Pietrasik, J., Sosińska, P., Kucińska, M., Murias, M., Maksin, K., Malińska, A., Ziółkowska, A., Piotrowska, H., Woźniak, A., \& Książek, K. (2014). Peritoneal mesothelium promotes the progression of ovarian cancer cells in vitro and in a mice xenograft model in vivo. Cancer Letters, 355(2), 310-315.

23. OECD. (2002). Test No. 420: Acute oral toxicity-fixed dose procedure. Paris: OECD.

24. Carstens, E., \& Moberg, G. P. (2000). Recognizing pain and distress in laboratory animals. ILAR Journal, 41(2), 62-71.

25. Qiao, Z., Redler, G., Epel, B., Qian, Y., \& Halpern, H. (2015). 3D pulse EPR imaging from sparse-view projections via constrained, total variation minimization. Journal of Magnetic Resonance, 258, 49-57.

26. Epel, B., Bowman, M. K., Mailer, C., \& Halpern, H. J. (2014). Absolute oxygen R1e imaging in vivo with pulse electron paramagnetic resonance. Magnetic Resonance in Medicine, 72(2), 362-368.

27. Decroos, C., et al. (2009). Oxidation of tris-(p-carboxyltetrathiaaryl)methyl radical EPR probes: Evidence for their oxidative decarboxylation and molecular origin of their specific ability to react with $\mathrm{O}^{-}-$. Chemical Communications, 1416-1418.

28. Przysiecka, Ł., et al. (2016). iRGD peptide as effective transporter of CuInZn x S $2+x$ quantum dots into human cancer cells. Colloids and Surfaces B, 146, 9-18.

29. Xue, J., et al. (2015). Highly enhanced fluorescence of CdSeTe quantum dots coated with polyanilines via in-situ polymerization and cell imaging application. ACS Applied Materials \& Interfaces, 7, 19126-19133.

30. Frisch, M. J., et al. (2009). Gaussian 09. Wallingford CT: Gaussian, Inc.

31. Weil, J. A. and Bolton, J. R. (2006) Electron Paramagnetic Resonance: Elementary Theory and Practical Applications, Second Edition, John Wiley \& Sons, Inc., Hoboken, NJ.

32. Elewa, M., Maltar-Strmečki, N., Said, M. M., El Shihawy, H. A., El-Sadek, M., Frank, J., Drescher, S., Drescher, M., Mäder, K., Hinderberger, D., \& Imming, P. (2017). Synthesis and EPRspectroscopic characterization of the perchlorotriarylmethyl tricarboxylic acid radical (PTMTC) and its 13C labeled analog (13CPTMTC). Physical Chemistry, Chemical Physics, 19, 6688-6697. 